\title{
MOLECULAR BASIS FOR RESISTANCE TO FLUAZIFOP-P-BUTYL IN ITCHGRASS (Rottboellia cochinchinensis) FROM COSTA RICA ${ }^{1}$
}

\author{
Base Molecular para Resistência a Fluazifop-P-Butyl em Capim-Camalote \\ (Rottboellia cochinchinensis) da Costa Rica
}

\author{
CASTILLO-MATAMOROS, R. ${ }^{2}$, BRENES-ANGULO, A. ${ }^{2}$, HERRERA-MURILLO, $\mathrm{F}^{3}$, and \\ GÓMEZ-ALPÍZAR. L. ${ }^{2}$
}

\begin{abstract}
Rottboellia cochinchinensis is an annual grass weed species known as itchgrass, or "caminadora" in America's Spanish speaking countries, and has become a major and troublesome weed in several crops. The application of fluazifop-P-butyl at recommended rates (125 g a.i. ha ${ }^{-1}$ ) was observed to be failing to control itchgrass in a field in San José, Upala county, Alajuela province, Costa Rica. Plants from the putative resistant R. cochinchinensis population survived fluazifop-P-butyl when treated with $250 \mathrm{~g}$ a.i. $\mathrm{ha}^{-1}$ (2X label rate) at the three- to four-leaf stage under greenhouse conditions. PCR amplification and sequencing of partial carboxyl transferase domain (CT) of the acetyl-CoA carboxylase (ACCase) gene were used to determine the molecular mechanism of resistance. A single non-synonymous point mutation from TGG (susceptible plants) to TGC (putative resistant plants) that leads to a Trp-2027-Cys substitution was found. This Trp-2027-Cys mutation is known to confer resistance to all aryloxyphenoxyproprionate (APP) herbicides to which fluazifop-P-butyl belongs. To the best of our knowledge, this is the first report of fluazifop-P-butyl resistance and a mutation at position 2027 for a Costa Rican R. cochinchinensis population.
\end{abstract}

Keywords: herbicide, mutation, acetyl-CoA carboxylase.

\begin{abstract}
RESUMO - Rottboellia cochinchinensis, espécie de planta daninha anual conhecida como capim-camalote, ou "caminadora", em países de lingua espanhola das Américas, tornou-se uma planta daninha significativa e problemática em diversas culturas. Observou-se que a aplicação de fluazifop-p-butyl nas doses recomendadas (125 gi.a. $\mathrm{ha}^{-1}$ ) não conseguiu controlar capim-camalote em uma região em San José, condado de Upala, província de Alajuela, Costa Rica. As plantas da população supostamente resistente de $\boldsymbol{R}$. cochinchinensis sobreviveram a fluazifop-p-butyl quando tratadas com $250 \mathrm{~g}$ i.a. ha ${ }^{-1}$ (2X a dose do rótulo) na fase de três a quatro folhas em condições de estufa. Amplificação e sequenciamento de reação em cadeia da polimerase de dominio de transferase de ácido carboxílico parcial (TC) do gene acetil-CoA carboxilase (ACCase) foram utilizados para determinar o mecanismo molecular de resistência. Foi encontrada uma mutação de ponto não sinônimo individual de TGG (plantas suscetiveis) para TGC (plantas supostamente resistentes) que conduz a uma substituição de Trp-2027-Cys. Sabe-se que essa mutação de Trp-2027-Cys confere resistência a todos os herbicidas ariloxifenoxipropionatos (AFP) a que fluazifop-p-butyl pertence. Pelo visto, este é o primeiro relato de resistência a fluazifop-p-butyl de uma mutação na posição 2027 para uma população costarriquenha de $\boldsymbol{R}$. cochinchinensis.
\end{abstract}

Palavras-chave: herbicida, mutação, acetil-CoA carboxilase.

Recebido para publicação em 1.6.2015 e aprovado em 18.8.2015.

2 Laboratorio de Biotecnología de Plantas, Centro de Investigaciones Agronómicas, San José, Costa Rica. <rolbin.castillomatamoros@ucr.ac.cr>; ${ }^{3}$ Estación Experimental Agrícola Fabio Baudrit Moreno, Universidad de Costa Rica, Alajuela Costa Rica. 


\section{INTRODUCTION}

Rottboellia cochinchinensis is an annual grass weed species known as itchgrass, pricklegrass, raoulgrass, corn grass, or "caminadora" in America's Spanish speaking countries. The first name refers to its fiberglass-like hairs on the sheaths and leaves that can cause severe skin irritation and infection on animals and humans, whereas the last name refers to its capacity to invade and progress into new areas (Valverde, 2004; Silva et al., 2009; Bolfrey-Arku et al., 2011). Itchgrass is native to India, but it is now present in more than 30 warm-climate countries of America, Africa, Asia and Oceania, and has become a major and troublesome weed in several annual crops including beans, cassava, cotton, maize, peanut, pineapple, sorghum, sugar cane, upland and rain-fed rice, and perennial crops such as banana, citrus, mango and oil palm at early growth stages (Bolfrey-Arku et al., 2011). Valverde (2004) has estimated that more than 3.5 million ha of crop areas are infested with itchgrass in Central America and the Caribbean alone, with crop yield losses up to $80-100 \%$ being reported in both tropical and subtropical conditions (Valverde, 2004; Bolfrey-Arku et al., 2011). In addition, the presence of itchgrass seeds in exported crop containers might result in rejection due to quarantine restrictions, leading to substantial economical losses for growers (García Fernández, 2007).

The primary method to control itchgrass is the use of pre and postemergence herbicides including Acetyl-coenzyme A carboxylase (ACCase)-inhibiting herbicides (Heap, 2014a,b; Avila et al., 2007; Sala, 2008). ACCase herbicides inhibit de novo fatty acid synthesis in sensitive grass weeds by binding to ACCase chloroplastic enzyme, leading to rapid necrosis and plant death (Incledon \& Hall, 1997; Kaundun, 2014). ACCase-inhibiting herbicides are divided into three chemichal classes, namely, aryloxyphenoxypropionates (APP or FOPs), cyclohexanediones (CHD or DIMs) and phenylpyrazolin (PPZ or DEN) (Kaundun, 2014). Fluazifop-P-butyl, a popular member of the APP class and commonly used to control itchgrass, is marketed in Costa Rica under various formulations (Horbowicz et al., 2013).
The continuous intensive use of ACCaseinhibiting herbicides and other single target site herbicides has led to the selection of weed resistant populations (Powles \& Yu, 2010). The mechanism of resistance to ACCaseinhibiting herbicides is either target-sitebased resistance (TSR) or non target-site-based resistance (metabolism-based resistance, NTSR) (Yu et al., 2004; Powles \& Yu, 2010; Délye et al., 2013; Mithila \& Godar, 2013; Kaundun, 2014). TSR is generally due to point mutations in the gene encoding the protein that is inhibited by the herbicide. This mutation results in a structural change in the binding site of the protein, ultimately decreasing its affinity for the herbicide (Yu et al., 2004; Powles \& Yu, 2010; Délye et al., 2013; Mithila \& Godar, 2013; Kaundun, 2014). TSR is also associated with herbicide crossresistance. In comparison, NTSR is complex, often polygenic in nature, and involves a large number of detoxifying enzymes, such as cytochrome P450 monooxygenases and gluthathione-S transferases, conferring multiple herbicide resistance (Délye et al., 2013; Mithila \& Godar, 2013; Kaundun, 2014).

Molecular and biochemical studies have established that the carboxyl transferase (CT) domain of the chloroplastic ACCase enzyme is the primary target-site of APP, CHD and PPZ herbicides (Délye, 2005; Powles \& Yu, 2010; Tao et al., 2010; Jang et al., 2013; Kaundun, 2014). Several point mutations in the gene encoding the CT domain have been identified and correlated with ACCase herbicide resistance in 43 grass weed species from around the world (Jang et al., 2013; Heap, 2014a; Kaundun, 2014). To date, eight spontaneous mutation sites, corresponding to fifteen allelic variants are known to confer resistance, namely Gln1756 to Glu, Ile1781 to Leu/Val/Ala/Thr, Trp1999 to Cys/Leu/Ser, Trp2027 to Cys, Ile2041 to Asn/Val, Asn2078 to Gly, Cys2088 to Arg, and Gly2096 to Ala/Ser (Li et al., 2013; Kaundun, 2014). Amino acid residues are identified according to their corresponding residue on EMBL/GenBank accession AJ310767, an ACCase gene sequence from Alopecurus myosuroides. Amino acid substitution at these eight positions can confer different patterns of resistance among ACCase-inhibitors. Generally, amino acid 
substitutions at positions 1999, 2027, 2041, and 2096 endow resistance to one or more APPs but not to CHDs or PPZ, while substitutions at 1781, 2078, and 2088 confer resistance to all three classes of herbicides (Powles \& Yu, 2010; Collavo et al., 2011; Jang et al., 2013).

Populations of $R$. cochinchinensis that have evolved resistance to ACCase-inhibiting herbicides have been identified in the USA (Heap, 2014b), Bolivia (Avila et al., 2007) and Ecuador (Sala, 2008), including fluazifop-Pbutyl, haloxyfop-R-methyl fenoxaprop, and cyhalofop-butyl from the APP group, and clethodim and sethoxydim from the CHD chemistry. Avila et al. (2007) have investigated resistance of itchgrass biotypes from Bolivia to haloxyfop-R-methyl (APP) and sethoxydim (CHD). Varying levels of resistance to haloxyfop-R-methyl and sethoxydim were found in different biotypes, and cross-resistance among graminicides was confirmed. In vitro ACCase assays have shown that the concentration of sethoxydim required to inhibit ACCase activity by $50 \%\left(\mathrm{I}_{50}\right)$ in the resistant biotypes was 11 times that of the sensitive biotype, indicating that resistant itchgrass biotypes had an ACCase enzyme that was relatively insensitive to the herbicide. These results have suggested that resistance in itchgrass biotypes might be conferred by a reduced sensitivity of the target enzyme, but definite proof that ACCase-inhibiting herbicide resistance is target-site was not presented.

In Costa Rica, many producers have complained about decreased control of Rottboellia cochinchinensis with fluazifop-Pbutyl applied at the recommended label rate, but to date resistance to ACCase herbicides in itchgrass has not been confirmed. Thus, the objective of the present study was to determine the molecular basis of the resistance in a $R$. cochinchinensis population from Costa Rica.

\section{MATERIALS AND METHODS}

\section{Plant material and herbicide treatment}

Seeds of a putative resistant $R$. cochinchinensis population were collected from surviving plants from a farm located in San José, Upala county $\left(10^{\circ} 51^{\prime} 10^{\prime \prime N}\right.$, $\left.85^{\circ} 2^{\prime} 17^{\prime \prime} \mathrm{W}\right)$, Alajuela province, Costa Rica, where the owner had observed that fluazifopP-butyl at label rates failed to control itchgrass. A known susceptible itchgrass population, collected in the Fabio Baudrit Moreno Agriculture Experimental Station, La Garita, Alajuela province, was included as a control.

Seeds were soaked in water for 18 hours and then air-dried for 12 hours. After drying, seeds were placed in a plastic box (520 x $260 \times 70 \mathrm{~mm})$ containing steam sterilized silty loam soil and were covered with a layer of soil. Following emergence, seedlings were transplanted into $16 \mathrm{~cm}$ diameter plastic pots (ten pots containing 10 seedlings each) containing the same soil as described before. When seedlings reached the three- to four-leaf stage, they were treated with $250 \mathrm{~g}$ a.i. ha ${ }^{-1}$ fluazifop-P-butyl, which represents $2 \mathrm{X}$ the label rate. Plants were daily monitored and visually assessed 3 weeks after treatment to determine if they were resistant (survived) or susceptible (dead). Two (2X) to three (3X) times of the recommended fluazifop-P-butyl field dose were frequently used as discriminatory doses between susceptible and resistant plants in several weeds (Scarabel et al., 2014; Jalaludin et al., 2014; Cha et al., 2014). In addition, $R$. cochinchinensis susceptible plants die when exposed to the recommended field dose (1X) in Costa Rica.

\section{DNA extraction}

Total genomic DNA was extracted from fresh leaf tissue of 3-week old seedlings of five resistant ( $R$ biotype) and five susceptible ( $S$ biotype) individual plants using a cetyltrimethylammonium bromide (CTAB) method modified from Saghai-Maroof et al. (1984).

\section{PCR amplification and sequencing}

Two sets of primers designed for use in grasses (Délye \& Michel, 2005) were used to amplify and sequence two regions (A and B) of the carboxyl transferase (CT) domain of the chloroplast directed ACCase gene, which contains all eight possible mutation sites known to confer resistance to ACCaseinhibiting herbicides. The first primer set, 
ACcp 1 (5'-CAACTCTGGTGCTNGGATNGGCA$\left.3^{\prime}\right)$ and ACcp $1 \mathrm{R}\left(5^{\circ}\right.$-GAACATANCTGAGCCACCT NAATATATT-3') amplified a 550-bp sequence (region A) containing the first two possible mutation sites Gln 1756 to Glu and Ile 1781 to Leu or Val. While the second primer set, ACcp4 (5'-CAGCNTGATTCCCANGAGCGNTC-3') and ACcp2R (5'-CCATGCANTCTTNGAGNTCCTC TGA-3) amplified a 406-pb sequence (region B) containing the remaining possible mutation sites Trp-1999-Cys, Trp-2027-Cys, Ile-2041Asn or Val, Asp-2078-Gly, Cys-2088-Arg and Gly-2096-Ala. The original sequences of the primers include I (inosine) instead of N (Délye $\&$ Michel, 2005). Primers were synthesized by Macrogen, Inc., Seoul, South Korea.

PCR amplification was performed in a final volume of $25 \mu \mathrm{L}$ including $2 \mu \mathrm{L}$ of crude DNA extract, $2.5 \mu \mathrm{L}$ 10X DreamTaq PCR of reaction buffer (Thermo Fisher Scientific), $1 \mu \mathrm{L}$ of each primer $(10 \mu \mathrm{M}), 2 \mu \mathrm{L}$ of nucleotide mix $(2 \mathrm{mM}), 1.7 \mu \mathrm{L}$ of $\mathrm{MgCl}_{2}(25 \mathrm{mM}), 1.0 \mu \mathrm{L}$ of BSA (20 mg mL $\mathrm{mL}^{-1}$ ), and $0.25 \mu \mathrm{L}$ of Dream Taq polymerase $(5 \mathrm{U} / \mu \mathrm{L})$ (Thermo Fisher Scientific), with $\mathrm{ddH}_{2} \mathrm{O}$ added to the final volume of $25 \mu \mathrm{L}$. The cycling conditions were DNA denaturation for $30 \mathrm{~s}$ at $95^{\circ} \mathrm{C}$, and 37 cycles of $10 \mathrm{~s}$ at $95^{\circ} \mathrm{C}, 15 \mathrm{~s}$ at $60{ }^{\circ} \mathrm{C}$ (first set of primers), or $61^{\circ} \mathrm{C}$ (second set of primers), and $45 \mathrm{~s}$ at $72{ }^{\circ} \mathrm{C}$; finally, a $10 \mathrm{~min}$ extension time at $72{ }^{\circ} \mathrm{C}$. The amplification was checked in a $1.6 \%$ agarose gel containing GelRed and visualized under UV light. PCR products were purified with the use of the NucleoSpin Extract II (Macherey-Nagel). The purified PCR products were sent to Macrogen Inc. (Seoul, South Korea) for sequencing in forward and reverse directions using the PCR primers. Sequence data (DNA and deduced amino acid) from $\mathrm{R}$ and $\mathrm{S}$ biotypes of $R$. cochinchinensis and from S plants of Alopecurus myosuroides (GenBank accessions AJ310767 and AJ 9666441), Aegilops cylindrical (GenBank accession AJ 966440) and Apera spica-venti (GenBank accession AJ 966442) were aligned and compared using BioEdit Sequence Alignment Editor Software (Hall, 1999).

\section{RESULTS AND DISCUSSION}

Ninety five percent of the putative resistant itchgrass plants survived fluazifop-
P-butyl when treated at the double of the recommended field rate.

DNA from 10 individual plants, five from putative resistant and five from susceptible $R$. cochinchinensis populations was extracted and successfully PCR amplified and sequenced with primers that had been designed to amplify regions $\mathrm{A}$ and $\mathrm{B}$ of the $\mathrm{CT}$ domain of the ACCase gene in grasses, which contain all known mutation sites that confer resistance to ACCase inhibiting herbicides (Délye \& Michel, 2005; Délye et al., 2011). Nucleotide and amino acid sequences were then aligned to each other and to the chloroplastic ACCase genes of other grass weeds (Figure 1).

The comparison of the nucleotide sequences of the region $\mathrm{B}$ of the $\mathrm{CT}$ domain within the ACCase gene of resistant and susceptible plants revealed a point mutation caused by a nucleotide change of TGG (susceptible plants) to TGC (resistant plants) (Figure 1A). These nucleotide substitution codes for an amino acid residue change at position 2027, numbering according to the coding sequence of Alopecurus myosuroides chloroplastic ACCase sequence (GenBank accession AJ310767), of tryptophan (Trp) in the susceptible plants to cysteine (Cys) in the resistant plants (Figure 1B). The nucleotide sequences were deposited in the GenBank database (Accession No. KM592092 and KM592093 for sensitive and resistant plants, respectively). All five resistant plants analyzed had the same point mutation at locus 2027. No other polymorphisms were observed in the examined regions (A and $\mathrm{B}$ ) of the $\mathrm{CT}$ domain between susceptible and resistant itchgrass plants. Nucleotide and amino acid polymorphisms were observed between $R$. cochinchinensis and the other grass weeds corresponding to species differences.

In Costa Rica, four weed species, Echinochloa colona (Junglerice), Ixophorus unisetus (Mexicangrass), Eleusine indica (Goosegrass), and Oryza sativa var. sylvatica (Red rice) have been confirmed as having herbicide-resistant biotypes, but only Junglerice has resistance to APP herbicides cyhalofop-butyl and fenoxaprop-P-ethyl (Valverde, 2007; Heap, 2014b), which belong to the same chemical class as fluazifop-P-butyl. Greenhouse and laboratory trials comparing a 


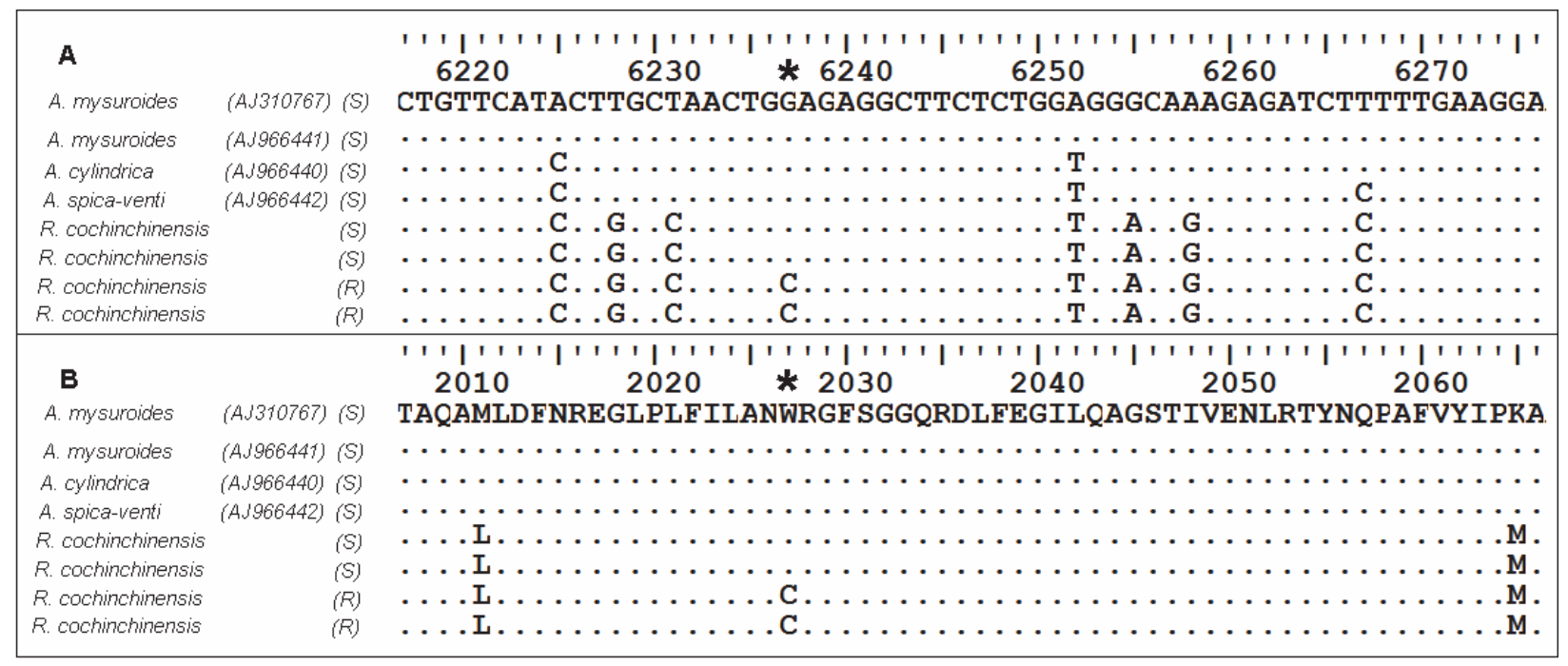

Numbers at the top of the sequences indicate nucleotide and amino acid positions within the A. myosuroides full ACCase sequence (GenBank AJ310767). Asterisk identifies where nucleotide or amino acid substitution occurred. Conserved nucleotides or amino acids are indicated by dots.

Figure 1 - Multiple alignment of partial nucleotide (A) and deduced amino acid (B) sequences of chloroplastic ACCase gene CT domain (Region B) from resistant (R) and susceptible (S) R. cochinchinensis biotypes and various weed species (GenBank accession numbers) susceptible to ACCase inhibiting herbicides.

known susceptible Junglerice biotype with the putative resistant Junglerice biotype have been used to confirm resistance; however, the mechanism of resistance has not been determined (Valverde, 2007; Heap, 2014b). To our knowledge, resistance of Costa Rica populations of $R$. cochinchinensis to ACCase-inhibiting herbicides has not been documented before, but decreased control of $R$. cochinchinensis with fluazifop-P-butyl applied at the recommended field rate (1X, $\left.125 \mathrm{~g}^{\mathrm{ia}} . \mathrm{ha}^{-1}\right)$ has been a frequent complaint by farmers in recent years. In the present study, 95\% of itchgrass plants were able to survive fluazifopP-butyl applied at $2 \mathrm{X}$ label rate (250 g a.i. ha-1) and might be considered resistant biotypes, since, normally, susceptible biotypes treated with the recommended field dose die. Similar results have been observed and confirmed for E. indica (Jalaludin et al., 2014; Cha et al., 2014), and Sorghum halepense (Johnsongrass) (Scarabel et al., 2014) treated with fluazifop-P-butyl at the double recommended field rate.

Resistant populations of $R$. cochinchinensis to ACCase-inhibiting herbicides have been identified in the USA (Heap, 2014 a,b), Bolivia (Avila et al., 2007, Valverde, 2007) and Ecuador
(Sala, 2008), including fluazifop-P-butyl. Resistance in itchgrass biotypes is conferred by a reduced sensitivity of the target enzyme, but definite proof that ACCase inhibiting herbicide resistance is target-site specific has not been presented (Avila et al., 2007). Here, for the first time, the comparison of the nucleotide and amino acid sequence of the $\mathrm{CT}$ domain of the ACCase gene from resistant and susceptible ichgrass plants revealed the presence of a target site mutation at position 2027 (Trp-2027-Cys). No other known mutations were found in the two examined regions of the CT domain. The Trp-2027-Cys mutation has been extensively shown to link to APPs-resistance in several grass weed species (Délye et al., 2005; Liu et al., 2007; Beckie et al., 2012; Gherekhloo et al., 2012; Kukorelli et al., 2013; Li et al., 2014) and particularly to fluazifop-P-butyl in Goosegrass (Cha et al., 2014; Jalaludin et al., 2014), Sudan grass (Kershner et al., 2012), and Japanese foxtail (Xu et al., 2013). Thus, it is our conclusion that a $R$. cochinchinensis population from Costa Rica has evolved resistance to fluazifop-P-butyl and the mechanism of resistance is based on an altered target site conferred by the Trp-2027-Cys mutation. 
Furthermore, since the Trp-2027-Cys mutation is known to confer resistance to all APPs herbicides while having small effects on the CHDs and DENs (Liu et al., 2007; Délye et al., 2008; Jang et al., 2013), our recommendation is that Costa Rican farmers should avoid the use of other members of the APPs group (e.g., fenoxaprop, haloxyfop and clodinafop), but they could still control APPs-resistant itchgrass populations using CHDs and DENs herbicides. Further studies are needed to verify this, since the same population could harbor individuals with different point mutations conferring resistance to ACCase herbicides from different groups, or individual plants could carry two different mutant sites that endow resistance to more than one ACCase herbicide group. Also, populations from different geographical areas could harbor different mutations (Yu et al., 2007; Liu et al., 2007; Cruz-Hipolito et al., 2011; Délye et al., 2010; Gherekhloo et al., 2012; Marshall et al., 2013; Li et al., 2013, 2014; Malone et al., 2014; Martins et al., 2014). In addition, the level of resistance depends on the number of resistant alleles in individual plants (Cha et al., 2014; Martins et al., 2014). Cha et al. (2014) have demonstrated that an $E$. indica biotype containing homozygous 2027-Cys allele could endow a higher level of resistance to fluazifop-P-butyl than a mix (heterozygous) Trp- and Cys-2027 allele biotype. Further research is needed to address these issues, for example, the collection of putative resistant individuals from different geoegraphical regions in order to determine which mutations are present in sequences of the CT domain of the ACCase gene. Crossresistance is also frequent, and enhanced metabolism or other resistant mechanisms should not be excluded (Cha et al., 2014). Considering the current knowledge base and the results from this study, it is our conclusion that Costa Rican farmers should consider the use of herbicides with alternative modes of action and other integrated control strategies in order to prevent the spread of fluazifop-Pbutyl resistant $R$. cochinchinensis biotypes.

\section{ACKNOWLEDGEMENTS}

The authors would like to acknowledge Dr. R.G. León, Assistant Professor, West Florida
Research and Education Center, University of Florida, Jay, FL 32565 and Dr. P.D. Esker, Professor, Crop Protection Center, University of Costa Rica, Costa Rica, for manuscript revisions and comments.

\section{LITERATURE CITED}

AVILA, W. et al. Characterization of the cross resistance mechanism to herbicides inhibiting acetyl coenzyme-A carboxylase in itchgrass (Rottboellia cochinchinensis) biotypes from Bolivia. Crop Protec., v. 26, n. 11, p. 342-348, 2007.

BECKIE, H. J. et al. Basis for herbicide resistance in populations of wild oat (Avena fatua). Weed Sci., v. 60, n. 1, p. 10-18, 2012.

BOLFREY-ARKU, G. E. K. et al. Seed germination ecology of itchgrass (Rottboellia cochinchinensis). Weed Sci., v. 59, n. 1, p. 182-187, 2011.

CHA, T. S. et al. Molecular basis for resistance to ACCaseinhibiting fluazifop in Eleusine indica from Malaysia. Pest Biochem Physiol., v. 111, n. 1, p. 7-13, 2014.

COLLAVO, A. et al. Characterisation and management of Phalaris paradoxa resistant to ACCase-inhibitors.

Crop Protec., v. 30, n. 3, p. 293-299, 2011.

CRUZ-HIPOLITO, H. et al. Mechanism of resistance to ACCase-inhibiting herbicides in wild oat (Avena fatua) from Latin America. J. Agric. Food Chem., v. 59, n. 39, p. 7261-7267, 2011.

DÉLYE, C. Weed resistance to acetyl-coenzyme A carboxylase inhibitors: an update. Weed Sci., v. 53, n. 5, p. 728-746, 2005.

DÉLYE, C.; MICHEL, S. "Universal” primers for PCRsequencing of grass chloroplastic acetyl-CoA carboxylase domains involved in resistance to herbicides. Weed Res., v. 45, n. 5, p. 323-330, 2005.

DÉLYE, C. et al. Molecular bases for sensitivity to acetylcoenzyme a carboxylase inhibitors in black-grass. Plant Physiol., v. 137, n. 3, p. 794-806, 2005.

DÉLYE, C. et al. Cross-resistance patterns to ACCaseinhibiting herbicides conferred by mutant ACCase isoforms in Alopecurus myosuroides Huds. (black-grass) re-examined at the recommended herbicide field rate. Pest Manage. Sci., v. 64, n. 11, p. 1179-1186, 2008.

DÉLYE, C. et al. Geographical variation in resistance to acetyl-coenzyme A carboxylase-inhibiting herbicides across the range of the arable weed Alopecurus myosuroides (blackgrass). New Phytol., v. 186, n. 4, p. 1005-1017, 2010. 
DÉLYE, C. et al. "Universal" PCR assays detecting mutations in acetyl-coenzyme A carboxylase or acetolactate synthase that endow herbicide resistance in grass weeds. Weed Res., v. 51, n. 4 , p. $353-362,2011$.

DÉLYE, C. et al. Deciphering the evolution of herbicide resistance in Weeds. Trends Genet., v. 29, n. 11, p. 649-658, 2013.

GARCÍA FERNÁNDEZ, B. Problemática comercial en piña por detección de semillas contaminantes de Rottboellia cochinchinensis. Proc. Caribbean Food Crops Soc., v. 43, n. 29, p. 16-22, 2007.

GHEREKHLOO, J. et al. Biochemical and molecular basis of resistance to ACCase inhibiting herbicides in Iranian Phalaris minor populations. Weed Res., v. 52, n. 4, p. 367-372, 2012.

HALL, T.A. BioEdit: a user-friendly biological sequence alignment editor and analysis program for Windows 95/98/ NT. Nucleic Acids Symp. Ser., v. 41, n. 1, p. 95-98, 1999.

HEAP, I. Global perspective of herbicide-resistant weeds. Pest. Manage Sci., v. 70, n. 9, p. 1306-1315, 2014a.

HEAP, I. International survey of herbicide resistant weeds, annual report internet, 2014b. Available in: <http:// www.weedscience.org/summary/MOASummary.asp $>$. Accessed: 16 maio 2014.

HORBOWICZ, M. et al. Effect of fluazifop-P-butyl treatment on pigments and polyamines level within tissues of non-target maize plants. Pest. Biochem. Physiol., v. 107, n. 1, p. 78-85, 2013.

INCLEDON, B. J.; HALL, J. C. Acetyl-coenzyme A carboxylase: quaternary structure and inhibition by graminicidal herbicides. Pest. Biochem. Physiol., v. 57, n. 3, p. 255-271, 1997.

JALALUDIN, A. et al. Multiple resistance across glufosinate, glyphosate, paraquat and ACCase-inhibiting herbicides in an Eleusine indica population. Weed Res., v. 55, n. 1, p. 82-89, 2014.

JANG, S.R. et al. Resistance to herbicides caused by single amino acid mutations in acetyl-CoA carboxylase in resistant populations of grassy weeds. New Phytol., v. 197, n. 4, p. 1110-1116, 2013.

KAUNDUN, S.S. Resistance to acetyl-CoA carboxylase inhibiting herbicides. Pest Manage Sci., v. 70, n. 9, p. 14051417, 2014.

KERSHNER, K.S. et al. Genetic resistance to AcetylCoenzyme A Carboxylase-Inhibiting herbicides in grain Sorghum. Crop Sci., v. 52, n. 1, p. 64-73, 2012.

KUKORELLI, G. et al. ACCase inhibitor herbicides selectivity, weed resistance and fitness cost: a review. Intern. J. Pest Manage., v. 59, n. 3, p. 165-173, 2013.
LI, L. et al. Molecular basis for resistance to fenoxaprop-Pethyl in American sloughgrass (Beckmannia syzigachne Steud.). Pest. Biochem. Physiol., v. 105, n. 1, p. 118-121, 2013.

LI, L. et al. Target-site mechanism of ACCase-inhibitors resistance in American sloughgrass (Beckmannia syzigachne Steud.) from China. Pest. Biochem. Physiol., v. 110, n. 1, p. 57-62, 2014.

LIU, W. et al. Single-site mutations in the carboxyltransferase domain of plastid acetyl-CoA carboxylase confer resistance to grass-specific herbicides. Proc. Nat. Acad. Sci. USA, v. 104, n. 9 , p. $3627-3632,2007$.

MALONE, J.M. et al. Distribution of herbicide-resistant acetyl-coenzyme A carboxylase alleles in Lolium rigidum across grain cropping areas of South Australia. Weed Res., v. 54, n. 1, p. 78-86, 2014.

MARSHALL, R. et al. The presence of two different targetsite resistance mechanisms in individual plants of Alopecurus myosuroides Huds, identified using a quick molecular test for the characterisation of six ALS and seven ACCase SNPs. Pest Manage Sci., v. 69, n. 6, p. 727-737, 2013.

MARTINS, B. A. B. et al. Alleles contributing to ACCaseResistance in an Italian Ryegrass (Lolium perenne ssp. multiflorum) population from Oregon. Weed Sci., v. 62, n. 3, p. 468-473, 2014.

MITHILA, J.; GODAR, A. S. Understanding genetics of herbicide resistance in weeds: implications for weed management. 2013. Adv Crop Sci Tech., v. 1, n. 4, p. 1-4, 2013.

POWLES, S. B.; YU, Q. Evolution in action: plants resistant to herbicides. Ann. Rev. Plant Biol., v. 61, p. 317-347, 2010.

SCARABEL, L. et al. Target-Site ACCase-Resistant Johnsongrass (Sorghum halepense) selected in summer dicot. Crops. Weed Technology, v. 28, n. 2, p. 307-315, 2014.

SAGHAI-MAROOF, M. A. et al. Ribosomal DNA spacerlength polymorphism in barley: Mendelian inheritance, chromosomal location, and population dynamics. Proc. Nat. Acad. Sci. USA, v. 81, n. 24, p. 8014-8019, 1984.

SALA, B. E. Determinación del nivel de sensibilidad de la Caminadora (Rottboellia cochinchinensis) como respuesta a la aplicación de cinco herbicidas con tres dosis diferentes y en cuatro zonas de la Provincia del Guayas. 2008. 102 f. Tesis de Ingeniero (Agrónomo) Escuela Superior Politécnica del Litoral, Guayaquil, Ecuador, 2008.

SILVA, C. E. B. et al. Germination aspects of itchgrass (Rottboellia cochinchinensis). Planta Daninha, v. 27, n. 2, p. 273-281, 2009.

Planta Daninha, Viçosa-MG, v. 34, n. 1, p. 143-150, 2016 
TAO, J. et al. Analysis of a critical residue determining herbicide efficiency sensitivity in Carboxyltransferase domain of Acetyl-CoA Carboxylase from Poaceae by Homology Modeling and Free Energy Simulation. Chem. Res. Chinese Univer., v. 26, n. 5, p. 816-821, 2010.

VALVERDE, B. E. Progress on Rottboellia cochinchinensis management. Available in: <http://www.fao.org/docrep/006/ y5031e/y5031e07.htm>. Accessed: 16 May 2014.

VALVERDE, B. E. Status and management of grass-weed herbicide resistance in Latin America. Weed Technol., v. 21, n. 2, p. 310-323, 2007.
XU, H. et al. Mechanism of resistance to fenoxaprop in Japanese foxtail (Alopecurus japonicus) from China. Pest. Biochem. Physiol., v. 107, n. 1, p. 25-31, 2013.

YU, Q. et al. Tolerance to acetolactate synthase and acetylcoenzyme A carboxylase inhibiting herbicides in Vulpia bromoides is conferred by two co-existing resistance mechanisms. Pest. Biochem. Physiol., v. 78, n. 1, p. 21-30, 2004.

YU, Q. et al. Diversity of acetyl-coenzyme A carboxylase mutations in resistant Lolium populations: evaluation using clethodim. Plant Physiol., v. 145, n. 2, p. 547-558, 2007. 